\title{
Sex Differences in Stroke
}

\author{
L. Christine Turtzo Louise D. McCullough
}

Department of Neurology and Neuroscience, University of Connecticut Health Center, Farmington, Conn., USA

\section{Key Words}

Stroke, gender $\cdot$ Stroke $\cdot$ Cerebral ischemia $\cdot$ Hormones

\begin{abstract}
Increasing evidence suggests that sex differences exist in the etiology, presentation, treatment, and outcome from stroke. The reasons for these sex disparities are becoming increasingly explored, but large gaps still exist in our knowledge. Experimental studies over the past several years have demonstrated intrinsic sex differences both in vivo and in animal models which may have relevance to our understanding of stroke in clinical populations. A greater understanding of the differences and similarities between males and females with respect to the risk factors, pathophysiology, and response to stroke will facilitate the design of future clinical trials and enhance the development of treatment strategies to improve stroke care in both sexes. This article reviews the current literature on sex differences in stroke with an emphasis on the clinical data, incorporating an analysis of bench research as it pertains to the bedside.
\end{abstract}

Copyright $\odot 2008$ S. Karger AG, Basel

\section{Introduction}

Each year 15 million people worldwide experience an acute stroke [1]. A third of those patients die secondary to their strokes, and another third experience permanent disability [1]. In developed countries, stroke is the third most common cause of death, after coronary heart disease and cancer [1]. While the overall incidence of stroke is declining in developed countries, the absolute number of strokes is increasing secondary to the aging of populations [1].

Investigations to date have demonstrated that the underlying etiology, causes and burden of stroke may be different for women and men. Differences in physiology between females and males may underlie some of the differences between the sexes seen in stroke. This paper reviews the literature on sex differences in stroke with a clinical focus, with discussion of laboratory research as it relates to the bedside. Our hope is that a better understanding of the similarities and differences between the sexes with respect to stroke will eventually lead to more effective therapies for this disease.

\section{Sex Differences in Stroke Epidemiology}

The incidence of stroke is higher in men until advanced age, with a higher incidence of stroke in women after age 85 years [2]. Each year more women than men die from stroke, with women accounting for $61 \%$ of deaths in the US in 2004 [2]. This difference may result from a combination of the longer life expectancy of women and the increasing incidence of stroke with age. There is a trend for increased stroke severity [3] and greater mortality in women versus men after stroke [2]. Of those with a first stroke, the percentage of those with a recurrent stroke within 5 years is higher in women than in men (22\% of women vs. $13 \%$ of men $40-69$ years old; $28 \%$ of women vs. $23 \%$ of men $\geq 70$ years old) [2].

Female sex is associated with poorer functional outcome after acute ischemic stroke (only $22.7 \%$ of women are fully recovered by 6 months vs. $26.7 \%$ of men) [3].

\section{KARGER}

(C) 2008 S. Karger AG, Basel

Fax +41613061234

E-Mail karger@karger.ch

www.karger.com
Accessible online at:

www.karger.com/ced
Louise D. McCullough, MD, PhD

Department of Neurology, University of Connecticut Health Center

263 Farmington Avenue

Farmington, CT 06030 (USA)

Tel. +1 860679 3186, Fax +1 860679 1181, E-Mail lmccullough@uchc.edu 
Women are more likely to be severely disabled at the time of discharge compared to men (36.1 vs. $24.2 \%$ ) [4]. Women are less likely than men to be discharged home after a stroke admission (40.9 vs. 50.6\%) [5], and are more likely to be discharged to long-term care upon hospital discharge (10 vs. $5 \%$ ) [6].

Some of these disparities in functional outcomes may be secondary to the older age of women at the time of first stroke ( 74.5 vs. 69.2 years) and the fact that women are more likely to have been institutionalized prior to their first stroke (7.9 vs. 3.7\%) [7]. After controlling for age, several studies found increased long-term mortality in men versus women after stroke [8-10] in contrast to other studies $[2,11]$.

Since women have strokes at older ages than men, age is a confounding factor in the analysis of these and other apparent sex differences in stroke and may diminish the effect of some of these discrepancies. However, some of these effects persist even after consideration of confounders. After controlling for confounding variables such as age, comorbidity, prestroke functional status, and stroke severity, women are less likely than men to receive a Barthel Index of 95 or greater (OR 0.75; 95\% CI 0.61-0.94) [12]. Even controlling for prestroke living conditions, more women than men still require institutional care at 3 months after stroke [13], and are less likely to achieve independence in activities of daily living [14].

Women are also more likely than men to report and experience depression after stroke [15-17], possibly making recovery from stroke more difficult $[18,19]$. Other important factors may include social support, sociocultural sex roles, and resources. Because women live longer than men, many more women are 'surviving spouses' and living alone; these individuals may have worse functional outcomes or simply be unable to care for themselves at home, although this has not yet been assessed in any prospective studies.

\section{Sex Differences in Acute Stroke Care}

Differences exist in the utilization of medical resources by men and women. A sex disparity in the access of patients to acute stroke care exists, with women $10 \%$ less likely to be admitted to the hospital within the first $3 \mathrm{~h}$ of stroke onset than men [20]. While several studies have found no statistical difference in intravenous (IV) tPA utilization between men and women during the treatment window [21, 22], a female stroke patient's overall chances of receiving thrombolysis are 13\% less than a male's [20]. A Canadian study found that this discrepancy persisted despite controlling for confounding variables including age, comorbidity, prestroke functional status, and stroke severity, with an OR of 0.51 for women to receive tPA relative to men (95\% CI 0.35-0.71) [12].

The disparity in a woman's chances to receive thrombolysis may be related to a delay in presentation beyond the 3-hour treatment window. As more elderly women live alone at the time of their first strokes [7, 13], and have unknown time of onset of symptoms, they may have difficulty reaching medical attention within the accepted 3hour window for IV tPA administration. However, one study found that the decreased likelihood of IV tPA treatment in women (OR 0.56; 95\% CI 0.37-0.86) persisted even when analysis was restricted to patients arriving within $2 \mathrm{~h}$ of symptom onset, and was most likely in patients younger than 75 years [23]. The possibility of potential 'undertreatment' of women needs to be carefully assessed as recent studies [24] suggest a possibility of improved recanalization rates in women compared to men after thrombolysis.

Several studies have investigated whether sex disparities exist in the response of patients to thrombolytic therapy. Analysis of pooled data from several American and European IV tPA trials found that women who received IV tPA between 0 and $6 \mathrm{~h}$ of symptom onset were more likely to have a modified Rankin score $\leq 1$ at 90 days poststroke than women who received placebo (40.5 vs. $30.3 \%$ ) [25]. Men, in contrast, did not have a statistically significant benefit from IV tPA treatment in this pooled analysis [25]. Another study found that women were more likely than men to demonstrate substantial neurological improvement in the first $24 \mathrm{~h}$ after IV tPA treatment (OR 2.4; 95\% CI 1.12-5.13) [26].

Results from the GAIN Americas trial found a different trend in patients treated within the approved 3-hour window. In this study, men were more likely than women to achieve better functional outcomes at 3 months by both the Barthel index and by a modified Rankin score [27]. A crucial limitation of the GAIN Americas study, however, is that rapid responders to IV tPA were excluded. Since women are more likely to show major neurological improvement in the first $24 \mathrm{~h}$ after IV tPA treatment [26], the exclusion of rapid responders from the GAIN Americas study may have negated the sex effect seen in the pooled analysis [25].

Similarly to IV tPA, women treated with intra-arterial (IA) prourokinase after middle cerebral artery occlusions showed a greater response to treatment than men (20 vs. 10\%) [28]. However, it is important to note that no sex 
disparity existed with respect to the IA thrombolytic treatment itself. Instead, a sex difference was noted in the untreated 'placebo' group, with only $17 \%$ of untreated women achieving a modified Rankin score of $0-2$ at 90 days versus $31 \%$ of untreated men [28], suggesting that functional outcomes are worse in untreated women.

The Canadian Alteplase for Stroke Effectiveness Study (CASES) examined outcomes in 615 men and 505 women who received IV tPA [29]. In contrast to the GAIN Americas trial, all patients, including early responders to tPA, were included in CASES [29]. No difference in 90-day functional outcome or mortality was seen between men and women treated with IV tPA in CASES [29]. CASES itself only enrolled stroke patients who had received tPA; therefore, data on functional outcomes in untreated patients are only available from historical controls. After stroke women have worse functional outcomes than men $[3,6,25]$. The absence of a gender difference in functional outcome at 90 days after IV tPA treatment in CASES suggests that tPA treatment may benefit women more than men, since untreated women would be more likely to do worse after stroke than untreated men.

Whether treatment with tPA leads to different recanalization rates between men and women is still a topic of debate, with one prospective analysis showing higher rates in women (94 vs. 59\%) treated with IV tPA [24], while a smaller study of IA tPA showed no differences [28]. Larger studies need to be designed to specifically determine if the risks and benefits of reperfusion therapies differ based on sex. The results of CASES suggest that these studies should be designed to not just look at treatment groups, but also at untreated patients, given that functional outcomes between the genders vary at baseline.

\section{Stroke Symptom Presentation}

Another possible explanation for the sex disparities seen in acute stroke care may be difficulty diagnosing a stroke at the prehospital level or in the emergency department. A prospective observational study of patients with validated stroke in community emergency departments found that women were more likely than men to present with nontraditional stroke symptoms such as pain, a change in level of consciousness, nonspecific, or unclassifiable neurological symptoms (28 vs. $19 \%$ ) [30]. Men were more likely than women to report traditional stroke symptoms such as hemiparesis or imbalance [30]. This sex difference in the rate of atypical presentation of stroke parallels that seen in acute myocardial infarction (MI) [31]. As women may present with nontraditional stroke symptoms, it may be more difficult for both patients and medical providers to recognize the clinical situation in a timely fashion. Additional clinical research is needed to identify barriers to care in women and improve access for all patients with acute stroke.

\section{Sex Differences in Stroke Evaluation}

Recent research suggests that not only do women have atypical stroke presentations that could potentially delay treatment, but they may undergo different diagnostic procedures once a stroke is identified. One American study found that $71 \%$ of males with ischemic stroke versus $62 \%$ of females with ischemia stroke underwent evaluation of their carotid arteries, and 57\% of men versus $48 \%$ of women had echocardiography, although MRI utilization rates were similar [32]. This is mirrored in European data as well. Women with stroke were less likely than men to have carotid duplex imaging (32.8 vs. $44.0 \%$ ), echocardiography (22.8 vs. $30.5 \%)$, or angiography (5.5 vs. 9.5\%) [7].

It has been known for some time that women tend to have more cardioembolic strokes than men, likely due to higher rates of atrial fibrillation in women $[4,13]$. A Spanish study recently found that women were less likely to experience lacunar and atherothrombotic strokes [4]. Rates of hemorrhagic stroke were not statistically different between women and men [4]. Whether or not the sex differences observed in diagnostic testing correlate with differences in stroke presentation and etiology is unknown. This merits further study to ensure that both men and women receive appropriate care after a TIA or stroke occurs.

\section{Sex Differences in Stroke Prevention: Atrial Fibrillation}

Atrial fibrillation is an independent risk factor for ischemic stroke, with an age-adjusted risk ratio of 4.8 [33]. For patients with both coronary artery disease and atrial fibrillation, the risk of stroke doubles in men, but increases almost 5-fold in women [34]. When off anticoagulation therapy, women with atrial fibrillation have higher annual incidence rates of both ischemic stroke and peripheral thromboembolism than men (3.5 vs. $1.8 \%$; RR 1.6) [35]. Both male and female patients with atrial 
fibrillation on anticoagulation therapy have reduced rates of thromboembolism (RR 0.6 and 0.4, respectively) [35]. Anticoagulation should be strongly considered for stroke prevention in all patients with atrial fibrillation; however, women may benefit even more than men from treatment. Reducing the time spent off anticoagulation may also be especially important for women.

\section{Sex Differences in Primary Stroke Prevention: Aspirin}

Previous clinical trials have largely ignored the potential for sex-specific responses to treatments or the possibility that endogenous or exogenous sex steroids may interact with treatments used for stroke treatment or prevention. However, there is now evidence of important sex differences in the response to pharmacological agents commonly prescribed for vascular disease prevention. Aspirin has been well-studied in the primary and secondary prevention of vascular disease.

The Women's Health Study evaluated 39,876 healthy women in order to determine the efficacy of aspirin for the primary prevention of cardiovascular events and stroke [36]. Women received either $100 \mathrm{mg}$ of aspirin every other day or placebo and were followed for 10 years. Aspirin lowered the risk of ischemic stroke by $24 \%$, but did not alter the risk of MI or death [36]. This finding is in direct contrast to those of the Physicians Health Study which examined a similar, but male-only cohort (fig. 1). In men, aspirin had no effect on stroke risk but substantially reduced the risk of MI [37]. A recent meta-analysis of aspirin efficacy for the primary prevention of cardiovascular events showed similar results [38]. Women treated with aspirin had a $17 \%$ risk reduction for stroke, but no reduction in MI rates or cardiovascular mortality [38]. In matched males, aspirin therapy reduced MI rates by $32 \%$ yet had no effect on stroke risk [38]. Whether similar clinical differences exist with respect to other antiplatelet agents or other pharmacological agents is currently unknown. The utilization of 'sex-specific' data analysis provides clear evidence that sex plays a critical role in the phenotypic expression of vascular disease and its treatment.

\section{Sex Differences in Secondary Prevention of Stroke: Medical Management}

A retrospective cross-sectional study in Scotland involving patients with stroke found a disparity in the use of accepted secondary prevention strategies between men and women [39]. While the overall age-standardized prevalence of stroke was higher in women than in men ( 2.8 vs. $2.6 \%$ ), women were less likely than men to be prescribed an angiotensin-converting enzyme inhibitor, a statin, or an antiplatelet in cases of ischemic stroke [39]. Of ischemic stroke patients with atrial fibrillation, women were not as likely to be prescribed warfarin as men but were more likely to be given an antiplatelet [39]. Another study found that men with over 85 years were more likely to get antiplatelet therapy than women of similar age after stroke [5]. In contrast, a prospective cohort study from Germany found few sex differences in medical management after stroke or TIA, with the exception that women were more likely to receive hypoglycemic agents in the acute management phase [40].

These sex differences in stroke management could have a profound clinical impact. Since women are more likely than men to have cardioembolic strokes, women with atrial fibrillation warrant treatment with warfarin when not contraindicated. Likewise, since women benefit more from aspirin for stroke prevention than men, aspirin should be considered for primary prevention. Given that women are more likely to have hypertension than men, blood pressure medications should be prescribed in women for stroke prevention according to JNC-7 guidelines [41]. This also holds true for women who have experienced a stroke, as vigorous risk factor control is required to prevent a future, potentially fatal, event.

\section{Sex Differences in Carotid Stenosis Management}

Women with ischemic stroke are less likely to have carotid surgery than men ( 0.3 vs. $1.5 \%)$ [7]. The riskbenefit ratio for surgical versus medical treatment of carotid stenosis differs in men and women and is also a topic of debate. While patients with symptomatic atherosclerotic carotid stenosis of $70-99 \%$ benefit from carotid endarterectomy $[42,43]$, female sex is classified as a surgical risk in these patients [44], with a higher risk of operative stroke and death in women than in men (systematic review of 25 studies: OR 1.31; 95\% CI 1.171.47) [45]. The long-term risk of stroke or death after surgery in patients with high-grade symptomatic carotid stenosis is the same between the sexes (HR 1.05) [46]. In patients with moderate symptomatic (50-69\%) [47, 48] and asymptomatic [49] carotid stenosis, men appear to benefit more from carotid endarterectomy surgery than women. 


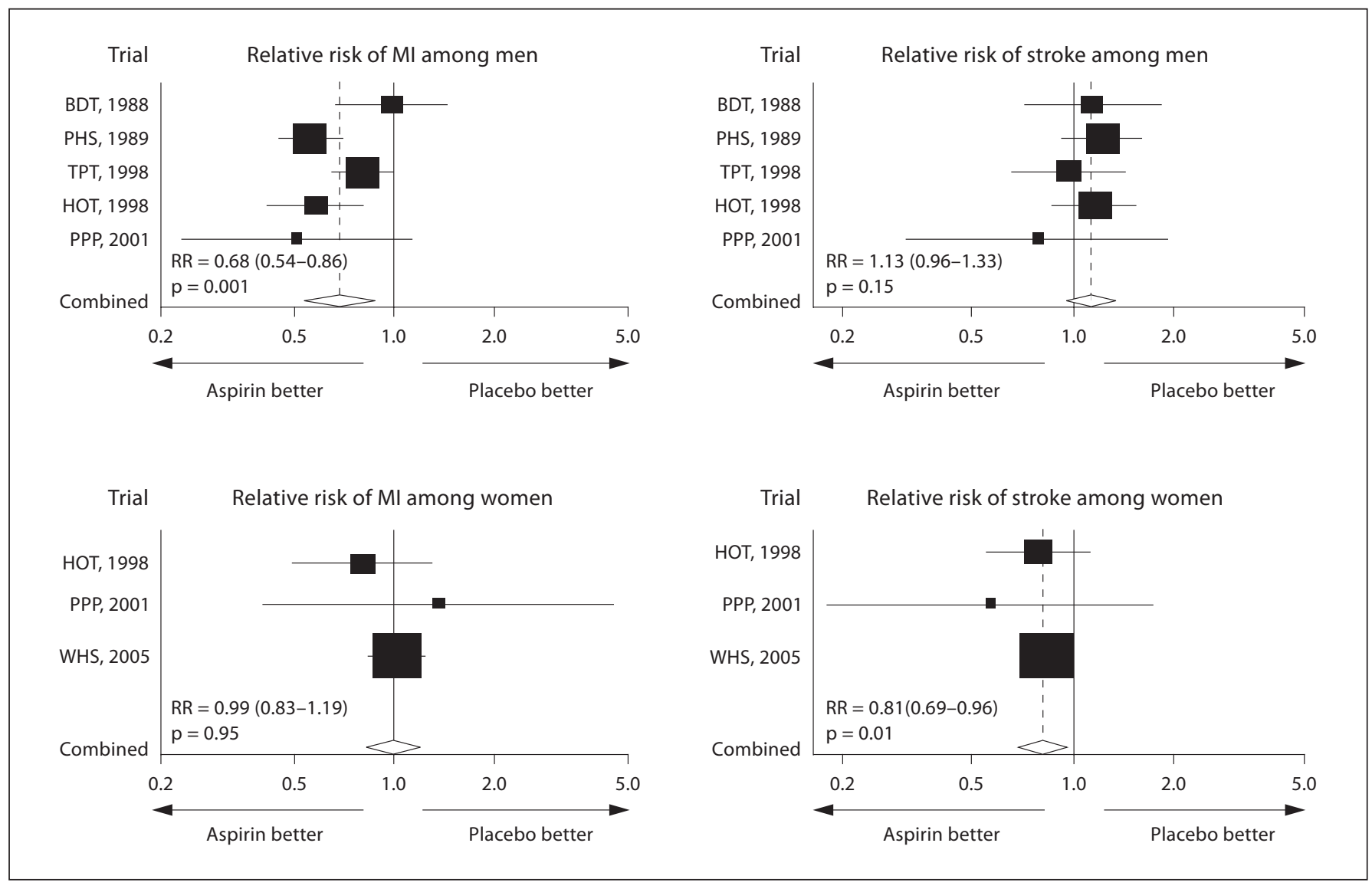

Fig. 1. Differential effect of aspirin on stroke risk and myocardial risk in men and women (reproduced with permission from the Massachusetts Medical Society from fig. 3 of Ridker et al. [36]; copyright (C) 2005 Massachusetts Medical Society; all rights re-

served). BDT $=$ British Doctors' Trial; PHS $=$ Physicians' Health Study; TPT $=$ Thrombosis Prevention Trial HOT $=$ Hypertension Optimal Treatment Trial; PPP = Primary Prevention Project; WHS = Women's Health Study.

Men with asymptomatic high-grade stenosis ( $\geq 70 \%)$ are at higher risk for vascular events than women when treated with medical management alone (HR 2.48), regardless of age or other vascular risk factors [50]. Interestingly, while there is no effect of treatment delay on response to carotid endarterectomy in men, one exists in women [51]. Women with symptomatic carotid artery stenosis benefit from carotid endarterectomy if the surgery is performed within 2 weeks of their most recent event, but the surgical benefit rapidly disappears if surgery is delayed beyond that point [51]. Whether these trends will be confirmed in larger studies, or if they are also present in patients that undergo carotid stenting, the necessity of dichotomizing trials and outcomes based on sex is becoming increasingly evident. 
Table 1. Hormone replacement trials in stroke

\begin{tabular}{|c|c|c|c|c|}
\hline Trial & Type & Age $^{1}$, years & Daily dose & Results \\
\hline WEST [55] & $\begin{array}{l}\text { Secondary prevention } \\
\text { of cardiac disease }\end{array}$ & $66.7(44-79)$ & $\begin{array}{l}0.625 \mathrm{mg} \text { conjugated equine estrogens } \\
2.5 \mathrm{mg} \text { medroxyprogesterone acetate }\end{array}$ & $\begin{array}{l}\text { No benefit in } \mathrm{CHD} \\
\text { risk }\end{array}$ \\
\hline HERS [54] & $\begin{array}{l}\text { Secondary prevention } \\
\text { of stroke }\end{array}$ & $71(46-91)$ & $1 \mathrm{mg}$ estradiol & $\begin{array}{l}\text { Higher risk of fatal } \\
\text { stroke }\end{array}$ \\
\hline WHI [57] & $\begin{array}{l}\text { Primary prevention } \\
\text { of stroke }\end{array}$ & $63.3(50-79)$ & $\begin{array}{l}0.625 \mathrm{mg} \text { conjugated equine estrogens } \\
2.5 \mathrm{mg} \text { medroxyprogesterone acetate }\end{array}$ & $\begin{array}{l}\text { Higher risk of } \\
\text { ischemic stroke }\end{array}$ \\
\hline $\begin{array}{l}\text { WHI estrogen } \\
\text { alone [124] }\end{array}$ & $\begin{array}{l}\text { Primary prevention } \\
\text { of stroke }\end{array}$ & $63.6(50-79)$ & $0.625 \mathrm{mg}$ conjugated equine estrogens & $\begin{array}{l}\text { Higher risk of } \\
\text { ischemic stroke }\end{array}$ \\
\hline KEEPS [64] & $\begin{array}{l}\text { Primary prevention } \\
\text { of stroke }\end{array}$ & $\begin{array}{l}\text { Enrolling ages } 42-58 \text { years } \\
\text { within } 36 \text { months of last } \\
\text { menstrual period }\end{array}$ & $\begin{array}{l}0.45 \mathrm{mg} \text { conjugated equine estrogens or } \\
50 \mu \mathrm{g} \text { transdermal estradiol } \\
200 \mathrm{mg} \text { progesterone } 12 \text { days/month }\end{array}$ & Study in progress \\
\hline
\end{tabular}

$\mathrm{CHD}=$ Coronary heart disease. ${ }^{1}$ Values represent mean with the range in parentheses.

vanced age, comorbid illnesses or decreased social support. Others may be secondary to failures to recognize stroke symptoms in women as easily as men, delaying treatment. Yet others result from differences in biology between men and women. Clearly new data on the effects of aspirin and response to tPA suggest that there are unknown biological differences between women and men. The next several sections will discuss stroke in the context of different hormonal environments which are unique to women.

\section{Hormone Replacement Therapy and Stroke}

Women are relatively 'protected' from stroke prior to the menopause, an effect that has been ascribed to gonadal hormones. Over the past 30 years, the majority of cohort, retrospective, or prospective observational studies have demonstrated significant reductions in cardiovascular disease in postmenopausal women receiving estrogen or combined estrogen-progestin therapy (HRT) $[52,53]$. Observational reports for stroke are not as clearly positive as those for cardiovascular disease [52]. Over the past decade, several major randomized clinical trials have been completed that address the role of HRT in both primary and secondary prevention of stroke. All trials to date have shown either no effect or an increased risk of stroke with treatment.

\section{HRT and the Secondary Prevention of Stroke}

Several randomized clinical trials investigated whether there is a role for HRT in the secondary prevention of stroke in postmenopausal women (table 1). Postmenopausal women with heart disease on HRT in the Heart and Estrogen/Progestin Replacement Study (HERS) trial showed no benefit with respect to cardiovascular disease endpoints. Treated women were at higher risk of thromboembolic events relative to placebo controls (relative HR 2.89) [54]. In the Women's Estrogen for Stroke Trial (WEST), postmenopausal women with a recent stroke or transient ischemic attack (within 90 days of randomization) treated with estradiol-17 $\beta$ experienced a higher risk of fatal stroke (RR 2.9) compared to placebo-treated women, with the majority of the risk attributed to an increase in fatal ischemic stroke (RR 4.4) [55]. The Stroke Prevention in Atrial Fibrillation (SPAF) III trial also showed an increased risk of ischemic stroke in postmenopausal women on estrogen replacement therapy (RR 3.2) [56]. Currently there is no role for the use of HRT for the secondary prevention of either heart disease or stroke.

\section{HRT and the Primary Prevention of Stroke}

The Women's Health Initiative (WHI) was a large multicenter double-blinded, randomized placebo-controlled trial that investigated the effect of estrogen plus 
progestin or estrogen alone for the primary prevention of stroke [57] (table 1). Both arms of this study were terminated early due to concerns of increased vascular risk in treated women. These results suggest that neither combined estrogen plus progestin nor estrogen treatment should be used for the primary prevention of stroke; however, the timing of hormone supplementation may be critical in interpreting these results.

\section{Timing and Age of Cohort/Estrogen Exposure}

Both the WHI Estrogen-Plus-Progestin Trial and the WHI Estrogen-Alone Trial have been the subject of great debate in the literature [58]. One major issue is the age of the women given estrogen. In laboratory models estrogen is potently neuroprotective when given immediately after menopause [59-63]. However, animals are usually young and are made 'surgically' menopausal via ovariectomy prior to an induced stroke. In clinical stroke, patients are often elderly, with all the associated comorbidities associated with aging. Women enrolled in the WHI were much older than women in the previous observational cohorts, and were often over a decade past menopause. The effect of returning estrogen to a possibly diseased vasculature after years of limited exposure may be detrimental.

Clinical trials are now underway to address whether or not the timing of HRT after menopause explains the discrepancy between our laboratory and clinical studies. The Kronos Early Estrogen Prevention Study (KEEPS) is a randomized, blinded, placebo-controlled multicenter clinical trial designed to address some of the problems noted with estrogen replacement in the WHI, WEST, and HERS trials [64]. Healthy women aged $42-58$ years who are recently menopausal, with no menses for a minimum of 6 and a maximum of 36 months prior to randomization are being enrolled in this 5-year trial [64]. KEEPS will examine the effect of oral $(0.45 \mathrm{mg}$ daily conjugated equine) or transdermal (50 $\mu$ g daily) estrogen with progesterone to placebo on carotid intimal medial thickness and coronary calcium deposition. It is important to note that these are surrogate markers rather than stroke incidence, as stroke is a relatively low incident event compared to coronary disease [64]. A subsequent analysis of the WHI data that segregated results based on age since menopause also showed no benefit of HRT on stroke [65]. Similar results have been found in the WHIMS cognitive dementia prevention trials [66-70]. The vast majority of previous studies used oral estrogen supplementation. This may increase the risk of thrombosis, as it leads to hypercoagulability, an effect that can be avoided with transdermal dosing.

Why are we having such difficulty translating the potentially beneficial effects of estrogen to humans? Many other neuroprotective agents have also failed to translate from bench to bedside [71], but the vast majority of these agents have not been as well studied as estrogen, which consistently shows beneficial effects in 'clinically relevant' animal models that are engineered to express common comorbid diseases such as diabetes and hypertension as well as in aging models [72, 73].

\section{Short-Term Effects of Estrogen in Stroke}

One possible reason for the failure of translation of estrogen's neuroprotective effects to humans may be secondary to the timing and duration of treatment. While clinical trials to date have focused on chronic estrogen treatment, experimental evidence indicates that acute, short-term estrogen treatment during reperfusion limits damage from induced cerebral ischemia in animal models $[63,74]$. Estrogen may enhance repair and plasticity after a stroke has occurred, as it has been shown to increase neurogenesis [75]. These data suggest that there may be a role for estrogen in the acute therapy of stroke during reperfusion, although no clinical data exist on this topic.

\section{Stroke in Pregnancy and the Postpartum Period}

While the risk of stroke in premenopausal women is in general much lower than postmenopausal women and older men, there is a higher incidence of stroke in women aged 15-35 compared to men [76], a period that coincides with the prime child-bearing years. For a more detailed clinical review of stroke in pregnancy, we direct the readers to an excellent recent review [77]. While several retrospective and prospective clinical trials have demonstrated an increased risk of stroke in pregnancy, data on stroke in pregnancy or the postpartum period in animal models are virtually nonexistent.

Only one animal study that examined the effects of pregnancy has been published which demonstrated increased neuronal damage in gestational day 17 pregnant rats after a global hypoxic insult [78]. It is important to note that the greatest risk for pregnancy-related strokes occurs in the peripartum and immediate postpartum period [79-82] rather than at end of pregnancy, and the ma- 


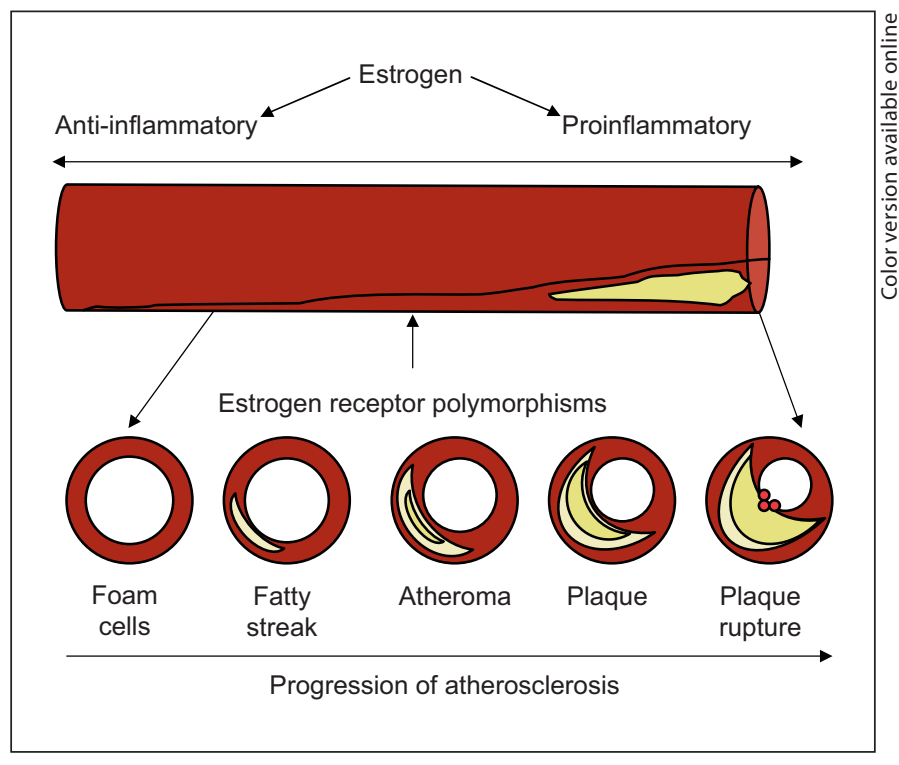

Fig. 2. Pleiotropic effects of estrogen depending upon the vasculature's degree of inflammation.

jority of events are not secondary to global hypoxic events. However, this work does represent the initial steps in evaluating this extremely complex clinical problem in an animal model.

The major identified risk factors for pregnancy-related stroke are preeclampsia and eclampsia [79, 83]. Late-stage pregnancy increases the permeability of the cerebrovasculature in animal models of acute hypertension and eclampsia [84], but how these effects are mediated and affect stroke risk is not yet understood. In addition, little is known about the specific effects of estrogen and progesterone on the cerebral vasculature in pregnancy or the postpartum period. Additional research is desperately needed in these areas.

\section{Preclinical Evidence for Estrogen's Effects on the Cerebrovasculature}

The protective effects of estrogen on endothelial health and vascular function have been well described in vitro [85-87] and in animal models $[88,89]$. It is increasingly clear that the overall effect of estrogen depends on the underlying health of the vessel (fig. 2). Substantial preclinical data demonstrate that the protective vascular effects of estrogen require treatment before significant vascular damage is underway, whereas adverse effects predominate once atherosclerosis is well established $[90,91]$.
For example, the protective effect of estrogen in ovariectomized monkeys fed atherogenic diets was only observed if there was no delay between ovariectomy and the start of hormone replacement [92]. A recent experimental study in mice confirmed that the timing of estrogen replacement is critical to stroke outcome [75]. As expected, estrogen treatment given immediately at the time of ovariectomy reduced stroke damage and attenuated central and peripheral production of proinflammatory cytokines. In contrast, estrogen treatment had no effect when it was administered 10 weeks postovariectomy and the animals were subsequently subjected to stroke. The interaction between age, estrogen, vasculature, inflammation, and duration of exposure is not yet clear in animal models, and certainly less so in women.

\section{Sex Steroid Hormone Receptors and Cerebrovascular Disease}

Estrogen interacts with two different nuclear receptors, ER- $\alpha$ and ER- $\beta$, both of which act in concert with other transcription factors to regulate gene expression $[85,89]$. ER- $\alpha$ is present in pial arteries and intracerebral blood vessels [93-95], localizing to both vascular smooth muscle cells and endothelial cells [93-95], and its protein expression is upregulated in cerebral blood vessels after in vivo treatment with estrogen [96]. Little is currently known about the role of ER- $\beta$ in the cerebral vasculature, although it has been detected in immunoblots of cerebral artery lysates $[89,93]$.

ER- $\alpha$ is thought to mediate most of the protective effects of estrogen on the vasculature. A 31-year-old man with a nonfunctional ER- $\alpha$ protein secondary to a premature stop codon in ESR1 had premature coronary atherosclerosis [97]. Certain polymorphisms of ESR1 have been associated with cerebrovascular [98-100] and cardiovascular disease [101-104] in men. Interestingly a different ESR1 polymorphism confers an increased risk of MI in women [105] (table 2), suggesting some interaction of ESR polymorphisms with sex or hormone exposure. However, several cross-sectional, case-control and cohort studies have not found any association between this polymorphism and risk of cardiovascular or cerebrovascular disease $[100,104,106,107]$. Variation in the ER- $\beta$ gene (ESR2) has also been associated with an increased risk of cardiovascular disease in women [108].

An interaction between sex, genetics, and vascular disease risk is suggested by the association of different ESR1 genotypes with cardiovascular disease in men in 
Table 2. Estrogen receptor polymorphisms

\begin{tabular}{|c|c|c|c|}
\hline Study & $\begin{array}{l}\text { Estrogen } \\
\text { receptor }\end{array}$ & Polymorphism/mutation & Association \\
\hline Case report [97] & $\mathrm{ER}-\alpha$ & Nonfunctional truncation & Premature coronary artery disease in male \\
\hline Case-control study [98] & $\mathrm{ER}-\alpha$ & PvuII polymorphism & Increased risk of stroke \\
\hline Prospective cohort study [103] & $\mathrm{ER}-\alpha$ & CC genotype of ESR1 c.454-397C & Increased risk of MI in men \\
\hline Prospective cohort study [105] & $\mathrm{ER}-\alpha$ & TT genotype of ESR1 c.454-397C & Increased risk of $\mathrm{MI}$ in females \\
\hline Prospective study [99] & $\mathrm{ER}-\alpha$ & CC genotype of ESR1 c.454-397C & Increased risk of stroke in men \\
\hline Case-control/cohort study [104] & $\mathrm{ER}-\alpha$ & ESR1 IVS1-397T/C polymorphism & No effect on risk of cardiovascular disease \\
\hline Case-control study [100] & ER- $\alpha$ & ESR1 c.454-397T $>C$ & No effect on stroke risk \\
\hline Case-control study [108] & ER- $\beta$ & ESR2 rs1271572 variant & $\begin{array}{l}\text { Increased risk of cardiovascular disease in } \\
\text { women }\end{array}$ \\
\hline
\end{tabular}

one study [103] but in women in another [105], and an association between different ESR2 genotypes and cardiovascular disease in women [108]. Given the genetic variability in humans, teasing out the underlying mechanisms will depend upon correlation with mouse models, in which the differences between genetic backgrounds can be more readily controlled.

\section{Sex versus Hormone Differences in Cell Death}

Recent evidence suggests that not all 'sex differences' are mediated by hormones. Increasing attention has been directed at sex as an important modulator of ischemic cell death pathways. In work by $\mathrm{Du}$ and colleagues it was found that cortical neurons derived from male (XY) versus female (XX) embryos had strikingly different responses to 'ischemic-like' insults [109]. Male cells were more sensitive to oxidant damage via a nitric oxide pathway, where female cells were much more sensitive to inducers of apoptosis and caspase-mediated cell death. Similarly, female-derived organotypic hippocampal slices experienced less injury than male-derived cultures when exposure to N-methyl-D-aspartic acid or oxygen and glucose deprivation [110]. When the neuronal nitric oxide synthase (nNOS) inhibitor 7-nitroindazole was added to these organotypic cultures, cell death after oxygen and glucose deprivation was lessened in male cultures but not in female cultures [110]. These findings have been confirmed in neonatal (where hormones are less of a contributor to outcome) and adult animal models of injury $[102,103]$.

A well-described pathway leading to ischemia-induced neuronal cell death results from the overstimulation of nNOS [110]. Increased nNOS activity results in enhanced production of nitric oxide, peroxynitrite for- mation, and nitrosative DNA damage and activation of the DNA repair enzyme poly(adenosine diphosphate-ribose) polymerase-1 (PARP-1) [110]. Genetic deletion of nNOS or PARP-1 is neuroprotective in male mice, but resulted in increased damage in female mice after middle cerebral artery occlusion [111]. Interestingly, both nNOS and PARP-1 knockout ovariectomized female mice showed no neuroprotective benefit of $17 \beta$-estradiol after middle cerebral artery occlusion, suggesting that interference with this pathway completely negates the beneficial effects of estrogen in vivo [111].

These data suggest that there are sexually dimorphic pathways leading to cell death after experimental ischemia. Whether these pathways are solely dependent upon sex steroid hormones or have any clinical relevance is presently under investigation. Data from a related mechanism of injury in neonatal animals, hypoxic-ischemic (HI) injury, may elucidate some of these answers.

\section{Sex Differences in Neonatal HI Injury}

Cerebral palsy (CP), which is typically secondary to an acquired injury, is more common in males than females [112]. The incidence of CP is $30 \%$ higher in males than females [113]. Even after preterm birth, female infants have better outcomes than males [114-117]; the reasons for this sex disparity are not understood. One type of injury that commonly leads to $\mathrm{CP}$ is a $\mathrm{HI}$ insult. $\mathrm{HI}$ has been studied extensively preclinically. In adult mice exposed to unilateral $\mathrm{HI}$, adult females exhibited less damage than males [118], presumably due to the neuroprotective effect of ovarian hormones. However, even in neonatal rodents, the response to $\mathrm{HI}$ injury in neonatal animals varied in a sex-specific manner, and differential cell death pathways 
were activated in the male versus the female brain [119]. These sex differences suggest that hormone exposure cannot fully explain the different responses to ischemia.

Moderate hypothermia after neonatal HI was more protective in female than male rat pups [120]. Disruption of the PARP-1 gene in mice protected males from perinatal HI, but not females [121], similar to the results seen in adult mice [111]. Immature (postnatal day 9) male mice displayed greater translocation of apoptosis-inducing factor, a downstream effect of PARP activation, in brain in response to $\mathrm{HI}$, while immature female mice had more activation of caspase-3 [118]. Agents used to treat neonatal HI experimentally also varied in their efficacy depending on the gender of the animal [122]. The caspase inhibitor Q-VD-OPh protected postnatal day 7 female rats from focal ischemia, while males showed no benefit, emphasizing the importance of caspase activation in the female brain [123].

These data suggest that different molecular mechanisms of brain injury are operational between the sexes that are unrelated to circulating sex hormone levels, as endogenous circulating estradiol is quite low in neonates. The organizational effects of steroids cannot be ignored and may still play some role in the response to ischemia but possible differences in basic ischemic cell death pathways are intriguing and merit further investigation. Clearly agents that are designed to interfere with $\mathrm{NO}$ or PARP signaling may have little effect or could paradoxi- cally increase damage in females. Similarly, interfering with caspase-mediated cell death in males may have little benefit. These are critical issues as we continue in our attempt to translate neuroprotection from the bench to the bedside.

\section{Conclusions/Further Directions}

Sex differences in stroke are present from the clinical through the molecular level. The reasons for these observed differences in clinical stroke between men and women are multifactorial, and merit further investigation. Once the reasons for these differences are better understood, intervention might be possible to help provide the best care for all patients. Some of the differences in clinical stroke result, however, from biological differences between males and females with respect to stroke. We are only just beginning to understand these sex differences at a molecular level and to elucidate the role of sex steroids in the outcome from ischemic injury.

\section{Acknowledgements}

We would like to thank Dr. Isaac Silverman for his helpful comments in reviewing an earlier draft of this manuscript. This work was supported by the NIH (5R01NS050505-02 and 5R01NS055215-02 to L.D.M.).

\section{References}

1 Mackay J, Mensah G: The Atlas of Heart Disease and Stroke. Geneva, World Health Organization, 2004

-2 Rosamond W, Flegal K, Friday G, Furie K, Go A, Greenlund K, Haase N, Ho M, Howard V, Kissela B, Kittner S, Lloyd-Jones D, McDermott M, Meigs J, Moy C, Nichol G, O’Donnell CJ, Roger V, Rumsfeld J, Sorlie P, Steinberger J, Thom T, Wasserthiel-Smoller S, Hong Y: Heart disease and stroke statistics - 2007 update: a report from the American Heart Association Statistics Committee and Stroke Statistics Subcommittee. Circulation 2007;115:e69-e171.

- 3 Niewada M, Kobayashi A, Sandercock PA, Kaminski B, Czlonkowska A: Influence of gender on baseline features and clinical outcomes among 17,370 patients with confirmed ischaemic stroke in the international stroke trial. Neuroepidemiology 2005;24:123-128.

-4 Roquer J, Campello AR, Gomis M: Sex differences in first-ever acute stroke. Stroke 2003;34:1581-1585.
5 Holroyd-Leduc JM, Kapral MK, Austin PC, Tu JV: Sex differences and similarities in the management and outcome of stroke patients. Stroke 2000;31:1833-1837.

-6 Kapral MK, Fang J, Hill MD, Silver F, Richards J, Jaigobin C, Cheung AM: Sex differences in stroke care and outcomes: results from the Registry of the Canadian Stroke Network. Stroke 2005;36:809-814.

7 Di Carlo A, Lamassa M, Baldereschi M, Pracucci G, Basile AM, Wolfe CD, Giroud M, Rudd A, Ghetti A, Inzitari D: Sex differences in the clinical presentation, resource use, and 3-month outcome of acute stroke in $\mathrm{Eu}$ rope: data from a multicenter multinational hospital-based registry. Stroke 2003;34: 1114-1119.

-8 Eriksson M, Norrving B, Terent A, Stegmayr B: Functional outcome 3 months after stroke predicts long-term survival. Cerebrovasc Dis 2008;25:423-429.

-9 Kimura K, Minematsu K, Kazui S, Yamaguchi T: Mortality and cause of death after hos- pital discharge in 10,981 patients with ischemic stroke and transient ischemic attack. Cerebrovasc Dis 2005;19:171-178.

-10 Pekmezovic T, Tepavcevic DK, Jarebinski M, Kostic M, Bumbasirevic L: Trends in mortality from different subtypes of stroke in the population of Belgrade (Serbia). Clin Neurol Neurosurg 2008;110:51-57.

11 Devroey D, Van Casteren V, Buntinx F: Registration of stroke through the Belgian Sentinel Network and factors influencing stroke mortality. Cerebrovasc Dis 2003;16:272279.

12 Reid JM, Dai D, Gubitz GJ, Kapral MK, Christian C, Phillips SJ: Gender differences in stroke examined in a 10 -year cohort of patients admitted to a Canadian teaching hospital. Stroke 2008;39:1090-1095.

13 Glader EL, Stegmayr B, Norrving B, Terent A, Hulter-Asberg K, Wester PO, Asplund K: Sex differences in management and outcome after stroke: a Swedish national perspective. Stroke 2003;34:1970-1975. 
14 Gargano JW, Reeves MJ: Sex differences in stroke recovery and stroke-specific quality of life: results from a statewide stroke registry. Stroke 2007;38:2541-2548.

15 Eriksson M, Asplund K, Glader EL, Norrving B, Stegmayr B, Terent A, Asberg KH, Wester PO: Self-reported depression and use of antidepressants after stroke: a national survey. Stroke 2004;35:936-941.

- 16 Everson SA, Roberts RE, Goldberg DE, Kaplan GA: Depressive symptoms and increased risk of stroke mortality over a 29year period. Arch Intern Med 1998; 158: 1133-1138.

17 House A, Knapp P, Bamford J, Vail A: Mortality at 12 and 24 months after stroke may be associated with depressive symptoms at 1 month. Stroke 2001;32:696-701.

18 Herrmann N, Black SE, Lawrence J, Szekely C, Szalai JP: The Sunnybrook Stroke Study: a prospective study of depressive symptoms and functional outcome. Stroke 1998;29: 618-624.

19 Parikh RM, Robinson RG, Lipsey JR, Starkstein SE, Fedoroff JP, Price TR: The impact of poststroke depression on recovery in activities of daily living over a 2-year follow-up. Arch Neurol 1990;47:785-789.

20 Foerch C, Misselwitz B, Humpich M, Steinmetz H, Neumann-Haefelin T, Sitzer M: Sex disparity in the access of elderly patients to acute stroke care. Stroke 2007;38:21232126.

-21 Lisabeth LD, Brown DL, Morgenstern LB: Barriers to intravenous tissue plasminogen activator for acute stroke therapy in women. Gend Med 2006;3:270-278.

$\checkmark 22$ Reed SD, Cramer SC, Blough DK, Meyer K, Jarvik JG: Treatment with tissue plasminogen activator and inpatient mortality rates for patients with ischemic stroke treated in community hospitals. Stroke 2001;32:18321840.

23 Gargano JW, Wehner S, Reeves M: Sex differences in acute stroke care in a statewide stroke registry. Stroke 2008;39:24-29.

24 Savitz SI, Schlaug G, Caplan L, Selim M: Arterial occlusive lesions recanalize more frequently in women than in men after intravenous tissue plasminogen activator administration for acute stroke. Stroke 2005; 36:1447-1451.

-25 Kent DM, Price LL, Ringleb P, Hill MD, Selker HP: Sex-based differences in response to recombinant tissue plasminogen activator in acute ischemic stroke: a pooled analysis of randomized clinical trials. Stroke 2005;36: 62-65.

-26 Saposnik G, Di Legge S, Webster F, Hachinski V: Predictors of major neurologic improvement after thrombolysis in acute stroke. Neurology 2005;65:1169-1174.

27 Elkind MS, Prabhakaran S, Pittman J, Koroshetz W, Jacoby M, Johnston KC: Sex as a predictor of outcomes in patients treated with thrombolysis for acute stroke. Neurology 2007;68:842-848.
28 Hill MD, Kent DM, Hinchey J, Rowley H, Buchan AM, Wechsler LR, Higashida RT, Fischbein NJ, Dillon WP, Gent M, Firszt CM, Schulz GA, Furlan AJ: Sex-based differences in the effect of intra-arterial treatment of stroke: analysis of the PROACT-2 study. Stroke 2006;37:2322-2325.

29 Kent DM, Buchan AM, Hill MD: The gender effect in stroke thrombolysis. Of CASES, controls, and treatment-effect modification. Neurology 2008, E-pub ahead of print.

30 Labiche LA, Chan W, Saldin KR, Morgenstern LB: Sex and acute stroke presentation. Ann Emerg Med 2002;40:453-460.

31 Meischke H, Larsen MP, Eisenberg MS: Gender differences in reported symptoms for acute myocardial infarction: impact on prehospital delay time interval. Am J Emerg Med 1998;16:363-366.

32 Smith MA, Lisabeth LD, Brown DL, Morgenstern LB: Gender comparisons of diagnostic evaluation for ischemic stroke patients. Neurology 2005;65:855-858.

33 Wolf PA, Abbott RD, Kannel WB: Atrial fibrillation as an independent risk factor for stroke: the Framingham Study. Stroke 1991; 22:983-988.

34 Wolf PA, Mitchell JB, Baker CS, Kannel WB, D’Agostino RB: Impact of atrial fibrillation on mortality, stroke, and medical costs. Arch Intern Med 1998;158:229-234.

- 35 Fang MC, Singer DE, Chang Y, Hylek EM, Henault LE, Jensvold NG, Go AS: Gender differences in the risk of ischemic stroke and peripheral embolism in atrial fibrillation: the anticoagulation and risk factors in atria fibrillation (atria) study. Circulation 2005; 112:1687-1691.

36 Ridker PM, Cook NR, Lee IM, Gordon D, Gaziano JM, Manson JE, Hennekens $\mathrm{CH}$, Buring JE: A randomized trial of low-dose aspirin in the primary prevention of cardiovascular disease in women. $\mathrm{N}$ Engl J Med 2005;352:1293-1304.

37 Final report on the aspirin component of the ongoing Physicians' Health Study. Steering Committee of the Physicians' Health Study Research Group. N Engl J Med 1989;321: 129-135

38 Berger JS, Roncaglioni MC, Avanzini F, Pangrazzi I, Tognoni G, Brown DL: Aspirin for the primary prevention of cardiovascular events in women and men: a sex-specific meta-analysis of randomized controlled trials. JAMA 2006;295:306-313.

39 Simpson CR, Wilson C, Hannaford PC, Williams D: Evidence for age and sex differences in the secondary prevention of stroke in Scottish primary care. Stroke 2005;36:1771-1775.

40 Müller-Nordhorn J, Nolte CH, Rossnagel K, Jungehülsing GJ, Reich A, Roll S, Villringer A, Willich SN: Medical management in patients following stroke and transitory ischemic attack: a comparison between men and women. Cerebrovasc Dis 2006;21:329-335.

41 Chobanian AV, Bakris GL, Black HR, Cushman WC, Green LA, Izzo JL Jr, Jones DW,
Materson BJ, Oparil S, Wright JT Jr, Roccella EJ: Seventh report of the joint national committee on prevention, detection, evaluation, and treatment of high blood pressure. Hypertension 2003;42:1206-1252.

42 North American Symptomatic Carotid Endarterectomy Trial Collaborators: Beneficial effect of carotid endarterectomy in symptomatic patients with high-grade carotid stenosis. N Engl J Med 1991;325:445-453.

$\checkmark 43$ Chaturvedi S, Bruno A, Feasby T, Holloway $\mathrm{R}$, Benavente $\mathrm{O}$, Cohen SN, Cote R, Hess D, Saver J, Spence JD, Stern B, Wilterdink J: Carotid endarterectomy - an evidence-based review: report of the Therapeutics and Technology Assessment Subcommittee of the American Academy of Neurology. Neurology 2005;65:794-801.

-44 Rothwell PM, Slattery J, Warlow CP: Clinical and angiographic predictors of stroke and death from carotid endarterectomy: systematic review. BMJ 1997;315:1571-1577.

45 Bond R, Rerkasem K, Cuffe R, Rothwell PM: A systematic review of the associations between age and sex and the operative risks of carotid endarterectomy. Cerebrovasc Dis 2005;20:69-77.

46 Kapral MK, Wang H, Austin PC, Fang J, Kucey D, Bowyer B, Tu JV: Sex differences in carotid endarterectomy outcomes: Results from the Ontario Carotid Endarterectomy Registry. Stroke 2003;34:1120-1125.

47 Barnett HJ, Taylor DW, Eliasziw M, Fox AJ, Ferguson GG, Haynes RB, Rankin RN, Clagett GP, Hachinski VC, Sackett DL, Thorpe KE, Meldrum HE, Spence JD: Benefit of carotid endarterectomy in patients with symptomatic moderate or severe stenosis. North American Symptomatic Carotid Endarterectomy Trial Collaborators. N Engl J Med 1998;339:1415-1425.

-48 Rothwell PM, Eliasziw M, Gutnikov SA, Warlow CP, Barnett HJ: Endarterectomy for symptomatic carotid stenosis in relation to clinical subgroups and timing of surgery. Lancet 2004;363:915-924.

49 Rothwell PM, Goldstein LB: Carotid endarterectomy for asymptomatic carotid stenosis: asymptomatic carotid surgery trial. Stroke 2004;35:2425-2427.

50 Dick P, Sherif C, Sabeti S, Amighi J, Minar E, Schillinger M: Gender differences in outcome of conservatively treated patients with asymptomatic high grade carotid stenosis. Stroke 2005;36:1178-1183.

-51 Rothwell PM, Eliasziw M, Gutnikov SA, Warlow CP, Barnett HJ: Sex difference in the effect of time from symptoms to surgery on benefit from carotid endarterectomy for transient ischemic attack and nondisabling stroke. Stroke 2004;35:2855-2861.

52 Paganini-Hill A: Hormone replacement therapy and stroke: risk, protection or no effect? Maturitas 2001;38:243-261.

53 Langer RD: Hormone replacement and the prevention of cardiovascular disease. Am J Cardiol 2002;89:36E-46E. 
-54 Hulley S, Grady D, Bush T, Furberg C, Herrington D, Riggs B, Vittinghoff E: Randomized trial of estrogen plus progestin for secondary prevention of coronary heart disease in postmenopausal women. Heart and Estrogen/Progestin Replacement Study (HERS) research group. JAMA 1998;280: 605-613.

55 Viscoli CM, Brass LM, Kernan WN, Sarrel PM, Suissa S, Horwitz RI: A clinical trial of estrogen-replacement therapy after ischemic stroke. N Engl J Med 2001;345:12431249.

56 Hart RG, Pearce LA, McBride R, Rothbart RM, Asinger RW: Factors associated with ischemic stroke during aspirin therapy in atrial fibrillation: analysis of 2,012 participants in the SPAF I-III clinical trials. The Stroke Prevention in Atrial Fibrillation (SPAF) Investigators. Stroke 1999;30:12231229.

57 Wassertheil-Smoller S, Hendrix SL, Limacher M, Heiss G, Kooperberg C, Baird A, Kotchen T, Curb JD, Black H, Rossouw JE, Aragaki A, Safford M, Stein E, Laowattana S, Mysiw WJ: Effect of estrogen plus progestin on stroke in postmenopausal women: the women's health initiative: a randomized trial. JAMA 2003;289:2673-2684.

58 Bushnell CD: Oestrogen and stroke in women: assessment of risk. Lancet Neurol 2005;4: 743-751.

-59 Simpkins JW, Rajakumar G, Zhang YQ, Simpkins CE, Greenwald D, Yu CJ, Bodor N, Day AL: Estrogens may reduce mortality and ischemic damage caused by middle cerebral artery occlusion in the female rat. J Neurosurg 1997;87:724-730.

60 Alkayed NJ, Harukuni I, Kimes AS, London ED, Traystman RJ, Hurn PD: Gender-linked brain injury in experimental stroke. Stroke 1998;29:159-166.

-61 Dubal DB, Kashon ML, Pettigrew LC, Ren JM, Finklestein SP, Rau SW, Wise PM: Estradiol protects against ischemic injury. J Cereb Blood Flow Metab 1998;18:1253-1258.

62 Hurn PD, Macrae IM: Estrogen as a neuroprotectant in stroke. J Cereb Blood Flow Metab 2000;20:631-652.

63 McCullough LD, Alkayed NJ, Traystman RJ, Williams MJ, Hurn PD: Postischemic estrogen reduces hypoperfusion and secondary ischemia after experimental stroke. Stroke 2001;32:796-802.

64 Harman SM, Brinton EA, Cedars M, Lobo R, Manson JE, Merriam GR, Miller VM, Naftolin F, Santoro N: KEEPS: the Kronos Early Estrogen Prevention Study. Climacteric 2005;8:3-12.

-65 Hendrix SL, Wassertheil-Smoller S, Johnson KC, Howard BV, Kooperberg C, Rossouw JE, Trevisan M, Aragaki A, Baird AE, Bray PF, Buring JE, Criqui MH, Herrington D, Lynch JK, Rapp SR, Torner J: Effects of conjugated equine estrogen on stroke in the Women's Health Initiative. Circulation 2006;113: 2425-2434
66 Shumaker SA, Legault C, Rapp SR, Thal L, Wallace RB, Ockene JK, Hendrix SL, Jones BN 3rd, Assaf AR, Jackson RD, Kotchen JM, Wassertheil-Smoller S, Wactawski-Wende J: Estrogen plus progestin and the incidence of dementia and mild cognitive impairment in postmenopausal women: the Women's Health Initiative Memory Study: a randomized controlled trial. JAMA 2003;289:26512662.

67 Rapp SR, Espeland MA, Shumaker SA, Henderson VW, Brunner RL, Manson JE, Gass ML, Stefanick ML, Lane DS, Hays J, Johnson KC, Coker LH, Dailey M, Bowen D: Effect of estrogen plus progestin on global cognitive function in postmenopausal women: the Women's Health Initiative Memory Study: a randomized controlled trial. JAMA 2003; 289:2663-2672.

68 Shumaker SA, Legault C, Kuller L, Rapp SR, Thal L, Lane DS, Fillit H, Stefanick ML, Hendrix SL, Lewis CE, Masaki K, Coker LH: Conjugated equine estrogens and incidence of probable dementia and mild cognitive impairment in postmenopausal women: Women's Health Initiative Memory Study. JAMA 2004;291:2947-2958.

69 Resnick SM, Coker LH, Maki PM, Rapp SR, Espeland MA, Shumaker SA: The Women's Health Initiative Study of Cognitive Aging (WHISCA): a randomized clinical trial of the effects of hormone therapy on age-associated cognitive decline. Clin Trials 2004; 440-450.

70 Espeland MA, Rapp SR, Shumaker SA, Brunner R, Manson JE, Sherwin BB, Hsia J, Margolis KL, Hogan PE, Wallace R, Dailey M, Freeman R, Hays J: Conjugated equine estrogens and global cognitive function in postmenopausal women: Women's Health Initiative Memory Study. JAMA 2004;291: 2959-2968.

71 O'Collins VE, Macleod MR, Donnan GA, Horky LL, van der Worp BH, Howells DW: 1,026 experimental treatments in acute stroke. Ann Neurol 2006;59:467-477.

72 Alkayed NJ, Murphy SJ, Traystman RJ, Hurn PD, Miller VM: Neuroprotective effects of female gonadal steroids in reproductively senescent female rats. Stroke 2000;31:161168.

73 Dubal DB, Wise PM: Neuroprotective effects of estradiol in middle-aged female rats. Endocrinology 2001;142:43-48.

74 Toung TJ, Traystman RJ, Hurn PD: Estrogen-mediated neuroprotection after experimental stroke in male rats. Stroke 1998;29: 1666-1670.

75 Suzuki S, Brown CM, Dela Cruz CD, Yang E, Bridwell DA, Wise PM: Timing of estrogen therapy after ovariectomy dictates the efficacy of its neuroprotective and antiinflammatory actions. Proc Natl Acad Sci USA 2007;104:6013-6018.

76 Bogousslavsky J, Pierre P: Ischemic stroke in patients under age 45. Neurol Clin 1992;10: $113-124$
77 Bushnell CD: Stroke and the female brain. Nat Clin Pract Neurol 2008;4:22-33.

78 Spencer SJ, Galic MA, Tsutsui M, Pittman QJ, Mouihate A: Effects of global cerebral ischemia in the pregnant rat. Stroke 2008;39: 975-982.

79 Kittner SJ, Stern BJ, Feeser BR, Hebel R, Nagey DA, Buchholz DW, Earley CJ, Johnson CJ, Macko RF, Sloan MA, Wityk RJ, Wozniak MA: Pregnancy and the risk of stroke. N Engl J Med 1996;335:768-774.

80 Salonen Ros H, Lichtenstein P, Bellocco R, Petersson G, Cnattingius S: Increased risks of circulatory diseases in late pregnancy and puerperium. Epidemiology 2001;12:456460 .

81 James AH, Bushnell CD, Jamison MG, Myers ER: Incidence and risk factors for stroke in pregnancy and the puerperium. Obstet Gynecol 2005; 106:509-516.

82 Bashiri A, Lazer T, Burstein E, Smolin A, Lazer S, Perry ZH, Mazor M: Maternal and neonatal outcome following cerebrovascular accidents during pregnancy. J Matern Fetal Neonatal Med 2007;20:241-247.

83 Sharshar T, Lamy C, Mas JL: Incidence and causes of strokes associated with pregnancy and puerperium. A study in public hospitals of Ile de France. Stroke in Pregnancy Study Group. Stroke 1995;26:930-936.

$>84$ Cipolla MJ, Vitullo L, Delance N, Hammer E: The cerebral endothelium during pregnancy: a potential role in the development of eclampsia. Endothelium 2005;12:5-9.

$>85$ Mendelsohn ME, Karas RH: The protective effects of estrogen on the cardiovascular system. N Engl J Med 1999;340:1801-1811.

>86 Miller AP, Feng W, Xing D, Weathington NM, Blalock JE, Chen YF, Oparil S: Estrogen modulates inflammatory mediator expression and neutrophil chemotaxis in injured arteries. Circulation 2004;110:16641669.

87 Orshal JM, Khalil RA: Gender, sex hormones, and vascular tone. Am J Physiol Regul Integr Comp Physiol 2004;286:R233R249.

88 Pelligrino DA, Galea E: Estrogen and cerebrovascular physiology and pathophysiology. Jpn J Pharmacol 2001;86:137-158.

89 Krause DN, Duckles SP, Pelligrino DA: Influence of sex steroid hormones on cerebrovascular function. J Appl Physiol 2006;101: 1252-1261.

-90 Harman SM, Naftolin F, Brinton EA, Judelson DR: Is the estrogen controversy over? Deconstructing the Women's Health Initiative Study: a critical evaluation of the evidence. Ann NY Acad Sci 2005;1052:43-56.

91 Bath PM, Gray LJ: Association between hormone replacement therapy and subsequent stroke: a meta-analysis. BMJ 2005;330:342.

$\checkmark 92$ Mikkola TS, Anthony MS, Clarkson TB, St Clair RW: Serum cholesterol efflux potential in postmenopausal monkeys treated with tibolone or conjugated estrogens. Metabolism 2002;51:523-530. 
93 Dan P, Cheung JC, Scriven DR, Moore ED: Epitope-dependent localization of estrogen receptor-alpha, but not -beta, in en face arterial endothelium. Am J Physiol Heart Circ Physiol 2003;284:H1295-H1306.

-94 Stirone C, Duckles SP, Krause DN: Multiple forms of estrogen receptor-alpha in cerebral blood vessels: regulation by estrogen. Am J Physiol Endocrinol Metab 2003;284: E184-E192.

-95 Stirone C, Boroujerdi A, Duckles SP, Krause DN: Estrogen receptor activation of phosphoinositide- 3 kinase, akt, and nitric oxide signaling in cerebral blood vessels: rapid and long-term effects. Mol Pharmacol 2005;67:105-113.

-96 Stirone C, Chu Y, Sunday L, Duckles SP, Krause DN: 17 Beta-estradiol increases endothelial nitric oxide synthase mRNA copy number in cerebral blood vessels: quantification by real-time polymerase chain reaction. Eur J Pharmacol 2003;478:35-38.

$\$ 97$ Sudhir K, Chou TM, Chatterjee K, Smith EP, Williams TC, Kane JP, Malloy MJ, Korach KS, Rubanyi GM: Premature coronary artery disease associated with a disruptive mutation in the estrogen receptor gene in a man. Circulation 1997;96:3774-3777.

-98 Zhang Y, Xie R, Wang Y, Chen D, Wang G, $\mathrm{Xu} \mathrm{X}$ : Association of estrogen receptor gene polymorphism with cerebral infarction, a case-control study. Zhonghua Yi Xue Za Zhi 2002;82:1443-1446.

-99 Shearman AM, Cooper JA, Kotwinski PJ, Humphries SE, Mendelsohn ME, Housman DE, Miller GJ: Estrogen receptor alpha gene variation and the risk of stroke. Stroke 2005;36:2281-2282.

100 Molvarec A, Szeplaki G, Kovacs M, Szeplaki Z, Fazakas A, Prohaszka Z, Fust G, Karadi I: Estrogen receptor alpha (ESR1) PvuII and XbaI gene polymorphisms in ischemic stroke in a Hungarian population. Clin Chim Acta 2007;382:100-105.

101 Lehtimaki T, Kunnas TA, Mattila KM, Perola M, Penttila A, Koivula T, Karhunen PJ: Coronary artery wall atherosclerosis in relation to the estrogen receptor 1 gene polymorphism: an autopsy study. J Mol Med 2002;80:176-180.

102 Lu H, Higashikata T, Inazu A, Nohara A, Yu W, Shimizu M, Mabuchi H: Association of estrogen receptor-alpha gene polymorphisms with coronary artery disease in patients with familial hypercholesterolemia. Arterioscler Thromb Vasc Biol 2002;22: 817-823.

103 Shearman AM, Cupples LA, Demissie S, Peter I, Schmid CH, Karas RH, Mendelsohn ME, Housman DE, Levy D: Association between estrogen receptor alpha gene variation and cardiovascular disease. JAMA 2003;290:2263-2270.
104 Kjaergaard AD, Ellervik C, Tybjaerg-Hansen A, Axelsson CK, Gronholdt ML, Grande P, Jensen GB, Nordestgaard BG: Estrogen receptor alpha polymorphism and risk of cardiovascular disease, cancer, and hip fracture: cross-sectional, cohort, and casecontrol studies and a meta-analysis. Circulation 2007;115:861-871.

105 Schuit SC, Oei HH, Witteman JC, Geurts van Kessel CH, van Meurs JB, Nijhuis RL, van Leeuwen JP, de Jong FH, Zillikens MC, Hofman A, Pols HA, Uitterlinden AG: Estrogen receptor alpha gene polymorphisms and risk of myocardial infarction. JAMA 2004;291:2969-2977.

106 Matsubara Y, Murata M, Kawano K, Zama T, Aoki N, Yoshino H, Watanabe G, Ishikawa K, Ikeda Y: Genotype distribution of estrogen receptor polymorphisms in men and postmenopausal women from healthy and coronary populations and its relation to serum lipid levels. Arterioscler Thromb Vasc Biol 1997;17:3006-3012.

107 Koch W, Hoppmann P, Pfeufer A, Mueller JC, Schomig A, Kastrati A: No replication of association between estrogen receptor alpha gene polymorphisms and susceptibility to myocardial infarction in a large sample of patients of European descent. Circulation 2005;112:2138-2142.

108 Rexrode KM, Ridker PM, Hegener HH, Buring JE, Manson JE, Zee RY: Polymorphisms and haplotypes of the estrogen receptor-beta gene (ESR2) and cardiovascular disease in men and women. Clin Chem 2007;53:1749-1756.

109 Du L, Bayir H, Lay Y, Zhang X, Kochanek PM, Watkins SC, Graham SH, Clark RS: Innate gender-based proclivity in response to cytotoxicity and programmed cell death pathway. J Biol Chem 2004;279:3856338570 .

110 Li H, Pin S, Zeng Z, Wang MM, Andreasson KA, McCullough LD: Sex differences in cell death. Ann Neurol 2005;58:317-321.

-111 McCullough LD, Zeng Z, Blizzard KK, Debchoudhury I, Hurn PD: Ischemic nitric oxide and poly (ADP-ribose) polymerase-1 in cerebral ischemia: male toxicity, female protection. J Cereb Blood Flow Metab 2005; 25:502-512.

112 Johnston MV, Hagberg H: Sex and the pathogenesis of cerebral palsy. Dev Med Child Neurol 2007;49:74-78.

-113 Jarvis S, Glinianaia SV, Arnaud C, Fauconnier J, Johnson A, McManus V, Topp M, Uvebrant P, Cans C, Krageloh-Mann I: Case gender and severity in cerebral palsy varies with intrauterine growth. Arch Dis Child 2005;90:474-479.

114 Ingemarsson I: Gender aspects of preterm birth. BJOG 2003;110(suppl 20):34-38.
115 Hintz SR, Kendrick DE, Vohr BR, Kenneth Poole W, Higgins RD, for The Nichd Neonatal Research Network: Gender differences in neurodevelopmental outcomes among extremely preterm, extremely-low-birthweight infants. Acta Paediatr 2006;95: 1239-1248.

-116 Sheiner E, Levy A, Katz M, Hershkovitz R, Leron E, Mazor M: Gender does matter in perinatal medicine. Fetal Diagn Ther 2004; 19:366-369.

117 Di Renzo GC, Rosati A, Sarti RD, Cruciani L, Cutuli AM: Does fetal sex affect pregnancy outcome? Gend Med 2007;4:19-30.

118 Zhu C, Xu F, Wang X, Shibata M, Uchiyama Y, Blomgren K, Hagberg H: Different apoptotic mechanisms are activated in male and female brains after neonatal hypoxia-ischaemia. J Neurochem 2006;96:1016-1027.

119 Hurn PD, Vannucci SJ, Hagberg H: Adult or perinatal brain injury: does sex matter? Stroke 2005;36:193-195.

120 Bona E, Hagberg H, Loberg EM, Bagenholm R, Thoresen M: Protective effects of moderate hypothermia after neonatal hypoxia-ischemia: short- and long-term outcome. Pediatr Res 1998;43:738-745.

121 Hagberg H, Wilson MA, Matsushita H, Zhu C, Lange M, Gustavsson M, Poitras MF, Dawson TM, Dawson VL, Northington F, Johnston MV: Parp-1 gene disruption in mice preferentially protects males from perinatal brain injury. J Neurochem 2004; 90:1068-1075.

-122 Nijboer CH, Groenendaal F, Kavelaars A, Hagberg HH, van Bel F, Heijnen CJ: Gender-specific neuroprotection by 2 -iminobiotin after hypoxia-ischemia in the neonatal rat via a nitric oxide independent pathway. J Cereb Blood Flow Metab 2007; 27:282-292.

123 Renolleau S, Fau S, Goyenvalle C, Joly LM, Chauvier D, Jacotot E, Mariani J, Charriaut-Marlangue C: Specific caspase inhibitor Q-VD-OPh prevents neonatal stroke in P7 rat: a role for gender. J Neurochem 2007; 100:1062-1071.

124 Anderson GL, Limacher M, Assaf AR, Bassford T, Beresford SA, Black H, Bonds D, Brunner R, Brzyski R, Caan B, Chlebowski R, Curb D, Gass M, Hays J, Heiss G, Hendrix S, Howard BV, Hsia J, Hubbell A, Jackson R, Johnson KC, Judd H, Kotchen JM, Kuller L, LaCroix AZ, Lane D, Langer RD, Lasser N, Lewis CE, Manson J, Margolis K, Ockene J, O'Sullivan MJ, Phillips L, Prentice RL, Ritenbaugh C, Robbins J, Rossouw JE, Sarto G, Stefanick ML, Van Horn L, WactawskiWende J, Wallace R, Wassertheil-Smoller S: Effects of conjugated equine estrogen in postmenopausal women with hysterectomy: the Women's Health Initiative randomized controlled trial. JAMA 2004;291:1701-1712. 